\title{
Perspective of development of cell techniques in veterinary medicine
}
A.Mazurkevych,
M. Maliuk,
V. Danilov,
V. Kovpak,
Yu. Kharkevych,

The purpose. To implement scientifically justified system of use of founder cells in veterinary cell regenerative medicine in view of world experience and reachings of domestic biology and veterinary medicine. Methods. Analytical, experimental, laboratory, clinical, comparative, statistical. Results. Main ways of wide implementation of methods of cell therapy in clinical veterinary medicine are offered. Conclusions. With the purpose to speed-up rates of development of domestic veterinary cell regenerative medicine it is necessary to concentrate forces of scientific, educational and practical sphere of range to implementation of methods of cell regenerative medicine into clinical practice through deepening scientific studies and spread of knowledge among specialists of veterinary medicine. To secure necessities of veterinary clinics in quality and safety products of cell techniques it is offered to develop a package of normative deeds (orders, instructions, rules, etc.). The offered system of use of donor founder cells in veterinary medicine allows reducing the price considerably of the method of regenerative medicine and to make it more accessible.

Key words: veterinary medicine, transplantation, founder cells, development of cell-like techniques.

Introduction. The use of stem cells (SC) in the clinical practice of veterinary medicine was made possible by phenomenal discoveries in biology and biotechnology. They are based on the ability of stem cells after their introduction into the organism of the recipient animal to restore the impaired cellular structure of one or another organ $[1,2,3]$.Especially rapid development of stem cell research has been developing in the last 20 years. Many publications on the results of studying of the stem cells properties in vitro and in vivo, the results of experimental and clinical trials, show the high relevance and promising use of membrane cells in biology, humane and veterinary medicine $[4,5]$.

As is known, stem cells are undifferentiated (immature) cells present in all multicellular organisms. In stem cells there is no specialization that is inherent in specialized cells. They restored themselves by symmetric and asymmetric fission [6].

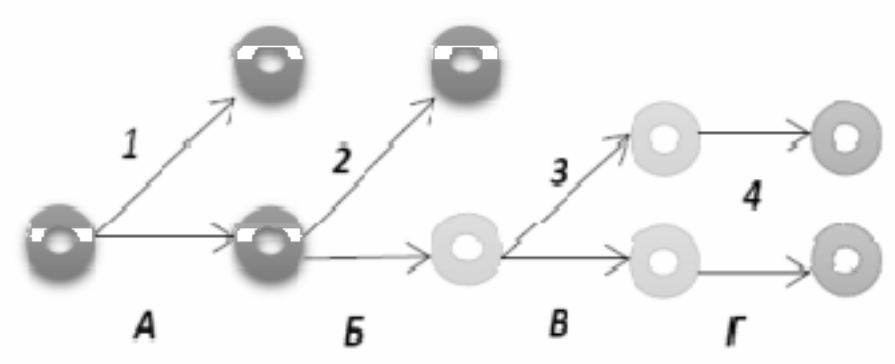


Differentiation of cells from stem $(A)$ in progenitor $(B)$ and in mature differentiated cells $(B) .1$ - symmetric division (mitosis), 2 - asymmetric cell division, 3 - progenitor division, 4 - end cell division, which goes to the GO phase of the cell cycle.

As a result of a symmetric division, appear two stem cells subsidiaries, while the asymmetric division gives one daughter stem cell and the other a precursor cell for other cell types. The precursor cell passes several stages of cell division and subsequently finally differentiated into a mature cell. Cells formed as a result of symmetric and asymmetric fission differ at each other molecular level, apparently due to their proteinaceous receptors on the cytoplasmic membrane.

It is in this way that animal's body restore cell composition of the organ or tissue and provide cellular homeostasis of the whole organism is throughout of its individual life.

Scientists have found that the quantitative composition of stem cells in the body varies with age. At the earliest stages of the development of the body of th, germ (fertilized oocyte and blastomeric 2 - 8 cell stage) completely consists of stem cells. These cells are attributed to totipotent ability to differentiate, since they can form all embryonic and extra-embryonic types of cells. The latter are able to form all types of embryonic cells and refer to pluripotent stem cells .In the newborn organism, the number of stem cells decreases to one stem cell by 10,000 specialized cells, and in adulthood this ratio is - 1 SC per 300,000 specialized cells [7].

The main site of stem cell formation in an adult organism is the bone marrow. In addition, in virtually all types of tissues isolated so-called tissue - specific stem cells.

In the process of aging, the stock of stem cells gradually depletes at different rates depending on the individual characteristics of the organism, the nature of the pathological processes that have been experienced and the environmental impact. Correspondingly, the possibilities for self-healing of its tissues also decrease.

Characteristic behavior of stem cells in the presence of pathological process in the organism, which is accompanied by intense destruction of its structure. Circulating in the blood, SC along with the tissue-specific SC through active reproduction gradually restore the broken structure of the tissue.In addition, it has been recently established that tissue-specific stem cells are able to differentiate into cells of other tissues due to their plasticity (the phenomenon of transdifferentiation ). Thus, the process of tissue regeneration occurs due to the activity of not only regional stem cells, but also due to the use of the circulatory cells in the blood and lymph of other lines of stem cells that are able to independently find damaged areas in tissues and restore them due to their ability to transdifferentiation [8].

A great biological meaning of such behavior of stem cells in the body, aimed at ensuring of structural integrity and cellular homeostasis of the body under physiological conditions and conditions of violations of the integrity of tissues or organs, is evident.

Despite the rapid development of research in the field of study of stem cells, far not all aspects of their biological properties have been studied. According to experts' conclusions, in the nearest decades the scope of use of stem cells in veterinary clinical practice will be considerably expanded. Already, science has the opportunity to offer manufacturing the latest methods of treatment of high-value animals: tribal, communicative and high-yielding.

The growth in demand for the use of SC and cellular technology products in veterinary cell regenerative medicine is gradually increasing and is aimed at finding new opportunities for extending the life and terms of use of breeding and productive animals, which for various reasons (liver, breast, ovarian, kidney, organ and tissues of the musculoskeletal system, etc.) are discarded due to the ineffectiveness of treatment with their traditional methods. These problems relate primarily to cattle breeding, horse breeding, sheep breeding, pig breeding, as well as the use of sports and communicative animals, and the preservation of the gene pool.

Despite all the prohibitions and inconsistencies in society regarding dilemmas: to use or not to use stem cells for treatment, cellular regenerative medicine is rapidly developing, offering to clinicians modern, highly 
effective, environmentally safe treatment methods that humanity has never used and which have their own future.

Studies of domestic scientists in this area are significantly behind the foreign ones, despite the fact that it was Ukrainian scientists who were one of the first to use stem cells for the effective treatment of patients, including foreign patients.

In 1992, Prof. O. Smicodub and his colleagues at the newly established private clinic, "EmCell" successfully treated patients with multiple sclerosis, diabetes, Alzheimer's disease, etc., using abortive embryos for this purpose.Abroad attempts to use SC with a medical purpose then just started.

Achievements of modern veterinary science and practice. Today, in spite of serious ethical and legal inconsistencies, in the scientific laboratories and clinics of different countries of the world, the development of technologies for treatment of patients with the use of stem cells is gaining momentum. The literature provides examples of successful treatment by stem cells of the most complex diseases that can not be treated by existing traditional methods.

In veterinary medicine, the use of SC for the treatment of animals originated almost simultaneously with the study of their properties in biology and humane medicine, since all experiments in medical laboratories are carried out precisely on animals. However, the results of such studies can not be used in veterinary medicine, since the specific properties of the SC of an animal origin require researchers to consider this in the methods of obtaining SC, their isolation, cultivation, storage and methods of application. In addition, questions of species sensitivity and the nature of the immune response from the body of recipient animals to donor cells remain unexplored. There are no established methods and multiplicity of cell administration and their dose. Despite the high relevance of the problem, scientific research is still in its infancy.

For the first time in Ukraine, research on the study of the properties of stem cells of animal origin and the possibilities of using cell technologies in veterinary cell regenerative therapy at the state level began in 2006 in the problematic scientific laboratory of physiology and experimental animal pathology of NULES of Ukraine.In a relatively short period of time, have been developed mediums for effective cultivation of SCs of different species of animals, and were established technological parameters of the processes for obtaining stem cells with the highest biological activity. For the first time embryonic stem cells from a 5-day embryo at the blastocyst stage were obtained after artificial insemination of the pig's egg in vitro by the original scheme and carried out directed differentiation of SC into cardiomyocytes.

According to the results of these studies, new or modified existing methods of cell material selection from animals of different species, isolation of mesenchymal stem cells from it using the corresponding technological regulations, which provide them with the highest biological activity [9], have been developed; high regenerative capacity of transplanted mesenchymal stem cells in restoration of experimentally damaged skin, articular cartilage, tendons, kidneys, liver, pancreas; the features of the immune response from the organism of recipient animals on the introduction of allogenic and xenogeneous mesenchymal stem cells (MSCs) $[10,11]$ were determined, characteristics of specific markers of MSC were identified as indicators for assessing of their biological activity and species specificity [12]; The influence of MSC on the peculiarities of the pathogenesis of the tumor process in the organism of recipient mice of so-called "high-precision" lines [13] was investigated.

In the organism of recipient animals, there is no immune response to allogeneic MSCs of this nature, as it is in the case of transplantation of organs and tissues, since MSCs release biologically active substances immunosuppressors that reduce sensitivity to them from the cells of the immune system [9,14].Therefore, their transplantation does not show their rejection, there is no need to choose an individual approach to use stem cells for the treatment of animals. At the introduction of xenogenous MSCs in animal recipients there are immune reactions, the strength of which, depending on the species of animals, leads to a decrease in the regenerative capacity of injected MSCs by $35-45 \%$. 
The results of the research were protected by 19 patents, included in scientifically substantiated methodological recommendations, as well as monographs, textbooks, manuals [15], scientific articles, reported at scientific forums, were covered on television and in other media.According to the results of research, 6 candidate and one doctoral dissertation, and more than 10 diploma papers of master's degree scholars have been prepared and defended. One doctoral student, 2 candidates for doctoral degree, 4 postgraduate students and masters for scientific specialization on the direction of "Cell technology in veterinary medicine" participated in scientific tasks .

The obtained results of experimental researches pass clinical approbation for further use in veterinary cellular regenerative therapy.New approaches to the use of allogeneic stem cells are proposed, which allows the use of SC from a single donor animal for the treatment of a group of other animals of the same species. The advantage of this approach is the ability to use cells from healthy donors to treat many animals of the same species, while the use of autogenic cell therapy involves treating a diseased animal only with its own SC. The latter significantly reduces the possibility of using SC and at times increases the cost of such treatment. By efficiency and safety, the method of using allogeneic SC is not inferior to the use of autogenic SC, which decreases the cost of treatment by an order and makes it accessible for wide use.

Development prospects. The object for the use of stem cells should be not only pets and communicative animals that are kept individually at home, but also highly valuable (productive, sporting, exotic, etc.) animals. Testing requires constant monitoring of the patient's health during the entire period of control.

In order to accelerate the pace of implementation of cell therapy methods in the veterinary clinical practice at NULES of Ukraine in 2016, a training and scientific laboratory "Center of Cell Technologies in Veterinary Medicine" was created.This is the first in Ukraine, and yet the only center in the field of veterinary medicine, in the medical industrie there is already 12 such centers. The mission of the Center is to further deepen research, improve the quality of the training of highly skilled scientific personnel and highly qualified specialists in veterinary medicine on the application of modern methods of cellular regenerative therapy of animals, as well as the dissemination of experience in veterinary medicine institutions.

The project of the concept of the development of cell technologies in veterinary medicine provides a complex of organizational measures for in-depth study of the properties of stem cells and other products of cell technologies, dissemination of their clinical experience with the use of the organization of the introduction of methods of veterinary cell regenerative therapy.

In the scientific sphere. Need further in-depth study of the particular application of stem cells to restore the structure and, accordingly, the functions of the mammary gland, myocardium, tissues of the musculoskeletal system, tissues of the reproductive system, eyes, other organs; for treatment of animals with oncological processes and others like that.

One of the unresolved issues in both humane and veterinary medicine is the lack of results of studying the properties of their own stem cells.

Modern scientific and practical actions are focused exclusively on the use of donor stem cells with a therapeutic (recovery) purpose in the recipient animal's organism in cases where obvious, irreversible changes are found which, in many cases, are no longer treated by traditional methods when their own stem cells are unable to provide the need for an organism to restore the structure of damaged tissues, or themselves cause pathological changes in these tissues.

But in the literature there is practically no information on the means and ways of increasing the potency of its own stem cells in the organism of the animal in physiological conditions and in conditions of the disease. There is no doubt that the results of such studies will allow us to take a different look at the role of substitute cell regenerative medicine, to get an answer to the question of the expediency of using transplantation of donor cell ? Where is the limit on which the body can not cope with the pathology itself? When to apply cell transplant, and when - to apply methods of stimulating the activity of their own SC? What methods of 
stimulation of their activity in the diseased organism can be used? For these and other questions, we will have answers in the future researches.

Another important and promising direction of the development of cell technologies in veterinary medicine should be the development of cellular engineering, in particular, in the issues of obtaining cell and tissue material of animal origin as an alternative source for its use in medical transplantology for human treatment.The possibility of using organs (liver, kidneys) of animals for transplantation to sick people in medical transplantology has been proven a long time ago.

As you know, a major problem in medical transplantology is the permanent shortage of transplant.According to experts, the annual need of the industry in donor agencies is on average 35-40 thousand and in connection with the massive mutilation of people in the ATO zone, this need has increased considerably in recent times. Many laboratories in the world have recently proved the ability to use artificial organs as an alternative source of transplants, which are obtained by forming a matrix on a special computer program and filling the matrix with appropriate lines of stem cells.Another area that is being intensively investigated is the use of organs from donor animals, in particular from pigs, with the human genotype.

The method of transplantation to humans of animal origin has its long history. However, because there is an immune response against the transplant in the recipient organism, usually ends with the rejection of the latter, doctors are forced to apply immunosuppressants for a long time to the recipient to avoid such rejection.Promising results were obtained by scientists from the United States, Australia, Spain, Great Britain, China, other countries, which, thanks to the latest advances in cellular engineering, received animal transplants that did not evoke a similar rejection reaction. These transplants are from piglets with a human genotype. So, on the eve of the future of transplantology, the result of scientific research, a colossal achievement.Organs obtained from such animals have a much lower antigenicity and do not cause immune responses from the body of the recipient. And the possibility of obtaining such donor materials from animal origin is virtually unlimited.

Unlike tissue grafts, stem cells not only have the lowest immunogenicity, but also have immunosuppressive activity.It has been shown that the recipient animals have virtually no immune response to the introduction of allogeneic stem cells (from an animal of the same species), as with the administration of autogenic (own) SCs, and therefore unable to cause immune responses from the body of the recipient animals.

Solving the problems of using stem cells and individual organs and tissues of animal origin in human rejuvenation therapy is a precept of time. It is extremely necessary and should be implemented jointly by researchers from veterinary, biology and medicine and related sciences.

In the practical field. As it is known, it takes some time to formulate a public opinion on the feasibility of using innovations on any issue. For example, we can give a history of the introduction of bone marrow transplantation to people to treat radiation sickness. After the first publication about successful treatment in humans using this method, it took six years before the widespread use of this method.

The proliferation of cell regenerative therapy in veterinary medicine also requires a certain amount of time, as well as active activity. Firstly, proper professional knowledge of the experts and owners of animals is needed regarding the efficiency and feasibility of using stem cells and cellular technology products in veterinary medicine, the cost of services, etc. Without deep knowledge of the somatic cell biology, it is impossible to develop scientific recommendations for obtaining, cultivation, storing cell material for acquiring active populations of SC; without studying the deep mechanisms of interaction between injected SC and the recipient organism is impossible, and sometimes dangerous, to prescribe stem cell treatment and to predict the level of effectiveness from their use. This requires an expanded training system for specialists with profound knowledge and skills in the field of cell technologies and clinical use of stem cells through a masters 
course and advanced training of veterinary doctors. All necessary conditions for this exist in NULES of Ukraine.

Secondly, in order to accelerate the implementation processes, it is necessary to create a network of veterinary clinics and facilities equipped with modern equipment and with a staff of skilled professionals with the right to use stem cells in their activities. The solution of this issue will become realistic as we spread knowledge and experience, rebuilding the minds of consumers - these most skilled professionals and animal owners.

Thirdly, introduction of methods of cellular technologies and cellular regenerative medicine is impossible without the development of a corresponding, adapted to international requirements, domestic regulatory framework. And such a base is necessary to accompany the necessary procedures and regulations in monitoring and control of the quality and safety of stem cells and cellular technology products in veterinary medicine; for the protection of recipient animals, donor animals; for establishing rules for specialists in the field of receiving, storing and transporting cellular materials and using them in regenerative therapywork.

The future of veterinary therapy is not by chemical means, but by means of natural origin.Further development of biotechnology and instrumental science and clinical practice, improvement of research methods will allow scientists in the near future to find and implement in the practice of the most environmentally friendly and the most effective and safe for the body therapeutic means of biopharmacology, and in particular products of cell technologies, to restore the lost structure and, accordingly, functions of an organism.In itself, the need to use existing synthetic pharmacological agents will be eliminated and to some extent will solve ecological toxicological, genetic and other problems.

\section{Conclusions}

In order to accelerate the development of domestic veterinary cell regenerative medicine, it is necessary to focus the efforts of the scientific, educational and practical spheres of the industry on the introduction of methods of cellular regenerative medicine into clinical practice through the deepening of scientific research and the dissemination of knowledge among specialists in veterinary medicine .To provide the needs of veterinary clinics in high-quality and safe products of cell technologies, it is proposed to complete a package of regulatory documents (regulations, regulations, etc.) .The proposed system for the use of donor stem cells in veterinary medicine significantly reduces the cost of regenerative medicine and makes it accessible to a wide range of users.

\section{References.}

1. Miki T., Strom S.C. Amnion-derived pluripotent/ multipolent stem cells // Stem Cell Rev.—2006.—Vol. 2.- P. 133-142.

2. Fortier LA. Stem cells: classifications, controversies, and clinical applications. Vet Surg 2005; 34(5): 415-423.

3. Hillebrands J.L. Origin of vascular smooth muscle cells and the role of circulating stem cells in transplant arteriosclerosis/ J.L. Hillebrands, F.A.Klatter, J. Rozing//Arterioscler. Thromb. Vasc. Biol.-2003.V.23.- №3.-P.380-387.

4. Джонатан Сарфрати. Стволовые клетки и Книга Бытия/ TJ 15(3):19-26, 2001.

5. Бутенко Г.М. Стовбурові клітини і проблема відновлення периферичних нервів/ Бутенко Г.М., Чайковський Ю.Б.// Здорове довголіття - 2013.- №5 (101). С.56 - 59.

6. Preston S. L. The new stem cells biology: something for every-one / S. L. Preston, M. R. S. J. Alison Forbes et. al. // Mol. Patol. - 2003. — Vol. 56. - P. 86 - 96.

7. Стволовые клетки - что это такое/ www.bibliotekar.ru/index.files/5stvolovye.htm. 
8. Петренко А. Ю. Стволовые кроветворные клетки из разных источников./ А. Ю. Петренко, В. И. Грищенко // Междунар. мед. журн. - 2003. - Т. 1. - С. $123-129$.

9. Використання мезенхімальних стовбурових клітин тваринного походження для корекції репаративних процесів в організмі тварин-реципієнтів. - Методичні рекомендації. //Мазуркевич А.Й., Данілов В.Б., Малюк М.О., Ковпак В.В., Харкевич Ю.О., Журба В. І., Бобось О.Л., Золтан Н.І. - К. 2012. — $42 \mathrm{c}$.

10. Мазуркевич А.Й. Стовбурові клітини у ветеринарній медицині. Том перший. Експериментальні дослідження з отримання, зберігання і застосування мезенхімальних стовбурових клітин / А.Й. Мазуркевич, М.О. Малюк, В.В. Ковпак, Ю.О. Харкевич, В.І. Журба. - К.: ТОВ ЦП «Компринт», 2013 266 c.

11. А.Й.Мазуркевич, В.В.Ковпак, Ю.О.Харкевич: Морфологічні зміни у підшлунковій залозі за алоксанового цукрового діабету у щурів// Науковий вісник НУБіП України. Серія «Ветер. медицина, якість і безпека продукції тваринництва» — 2015. - №227. —c.155-159.

12. Mazurkevych A., Malyuk M., Bezdieniezhnykh N., Starodub L., Kharkevych Y., Brusko E., Gryzińska M., Jakubczak A. Immunophenotypic characterisation and cytogenetic analysis of mesenchymal stem cells from equine bone marrow and foal umbilical cords during in vitro culture// J.of Veter. Research/form. Bull. of the Vet. Institute in Pulawy. - Vol. 60, Iss.3 (Sep 2016).- P. 339 - 347.

13. Кладницька Л.В., Ковпак В.В.: Життєздатність та проліферативна активність мезенхімальних стовбурових клітин лінійних мишей с 57b//6 залежно від умов виділення первинного матеріалу/ Наук.вісник НУБіП України: Серія «Ветеринарна медицина» - К., 2013. — Вип. № 188 , Ч.3. — С. 578-585.

14. Pittenger M.F. Multilineage potential of adult human stem cells / Pittenger M.F., Mackay A.M., S.C Beck et al. Science. - 1999. - Vol. 284. - P. 143 - 147.

15. Клітинні технології у ветеринарній медицині. Навчальний посібник// Мазуркевич А.Й., Ковпака В.В., Данілов В.Б., Малюк М.О., Харкевич Ю.О.- Київ 2014. - 131 с. 